\section{SAAAA \\ JOURNAL}

Open Access
Journal of Archaeology and Fine Arts in Southeast

Asia

Published by the SEAMEO Regional Centre for Archaeology and Fine Arts (SPAFA)

\title{
Inao of King Rama II: The Transformation of the Panji Stories into a Masterpiece of Thai Court Drama Literature
}

Dr Thaneerat Jatuthasri

Lecturer

Department of Thai

Faculty of Arts

Chulalongkorn University

thaneerat_j@hotmail.com http://www.spafajournal.org

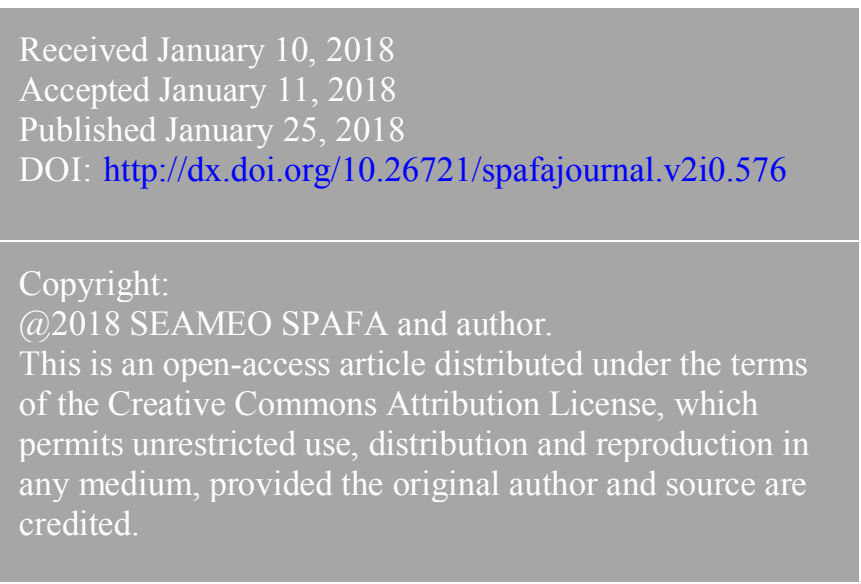

\begin{abstract}
This paper aims to examine how Inao of King Rama II was composed from the Panji stories and became a masterpiece of Thai court drama literature and how the story is unique as a Thai literary work. It finds that Inao of King Rama II developed from the Panji stories and contains various elaborations, embellishments and innovations, in order to serve the purposes of Lakhon Nai and Thai literature. A perfect combination of prominent features from other Panji stories and new creations in its Thai adaptation makes Inao a reference for excellence in literature and the performing arts. This paper was presented at the Seminar and Performances of a Shared Heritage: The Panji/Inao Traditions in Southeast Asia, organized by SEAMEO SPAFA on 2-6 March 2013 at the Bangkok Cha-Da Hotel and the Thailand Cultural Centre, Bangkok, Thailand.
\end{abstract}

Keywords: Classical Thai literature; Inao; Panji; King Rama II; Thai court dance drama

\section{Introduction}

The Panji stories originated in East Java and became widespread throughout Southeast Asian countries such as Malaysia, Thailand, Burma, Cambodia, Laos and Singapore. There are numerous versions of the Panji stories. "Each story appears to 
contain the same (or a very similar) nucleus of plot, embroidered with narrative detail in varying amounts and of varying content, thus giving rise to the different titles bestowed on the various works" (Robson 1969: 11). Each Panji story shares the same heroic theme: the loves and adventures of a legendary Javanese prince generally called Inu or Panji.

The Javanese and Malay Panji stories were introduced to the Thai court around the $18^{\text {th }}$ century in the reign of King Barommakot in the late Ayutthaya period. Based on the Panji stories they had heard, the two daughters of King Barommakot composed two Panji stories in the form of Thai court drama literature in order to be performed as a Thai court dance drama or Lakhon Nai. The elder princess composed Dalang, while the younger princess composed Inao (Damrongrachanuphap 1965: 103). Before the two Panji stories were composed and performed in the court, the repertoires of the Thai court dance drama were solely based on the Ramakien and Unnarut Indian epics.

Later on, Inao and Dalang were recomposed by King Rama I (1782-1809). The story of Dalang by King Rama I was complete, but only seven episodes of the Inao survived. In the reign of King Rama II (1809-1824), the king rewrote the Inao of King Rama I in order to add more literary beauty and to better serve as a Thai court dance drama (Damrongrachanuphap 1965: 140).

Among Thai audiences, the story of Inao is much more popular than that of Dalang. The story of Inao provides the inspiration for creating various kinds of art such as works of literature, paintings, songs, performances and even television dramas. For example, there is a set of Inao paintings on the wall in the vihara of Sommanat Temple in Bangkok painted by a court artist around the $19^{\text {th }}$ century.

Among the variations of the Thai Panji story, Inao is a masterpiece of King Rama II and is the most complete Thai Panji story. This work represents a favourite among Thai audiences and received praised from Wannakhadi Samoson (the Thai literary association) during the reign of King Rama VI as the best work of Thai dance dramas. Though it was composed over two hundred years ago, to this day, it is still well known. Inao of King Rama II thus calls for further attention. This paper aims to examine how Inao of King Rama II was composed from the Panji stories and became a masterpiece of Thai court drama literature and how the story is unique as a Thai literary work.

\section{Synopsis of Inao}

There are four important kingdoms at the time of the story: Kurepan, Daha, Kalang and Singhatsari. The rulers of these four kingdoms are brothers. The crown prince of Kurepan, Inao and the princess of Daha, Butsaba, have been arranged for marriage by their fathers since they were young. Nonetheless, Inao has not had the chance to meet Butsaba.

When Inao meets another girl, Chintara, he breaks off his engagement. Butsaba's father, the king of Daha, is so angry with Inao that he gives Butsaba to the king of Choraka, the first man who asks for her. After that, the king of Kamangkuning tries to force the king of Daha to give Butsaba to his son, Wiyasakam, who falls in love with 
Butsaba after seeing her picture, but the king of Daha refuses, thus leading to a war between Daha and Kamangkuning. The king of Kurepan, Inao's father as well as the king of Daha's elder brother, orders Inao to help the king of Daha fight against the king of Kamangkuning.

After defeating the king of Kamangkuning, Inao enters Daha to salute the king, which gives him his first chance to meet Butsaba. Upon seeing her, he immediately falls in love with her and realizes his foolish mistake in breaking off the engagement. Inao then decides to kidnap Butsaba. This causes Patarakala, the ancestor god of the four kingdoms, to be very angry with Inao.

Patarakala punishes Inao by separating Butsaba from Inao and casts a spell so that Inao and Butsaba will not recognize each other unless the siblings of the four kingdoms meet together. Thus begins Inao's great adventure to seek out his lost lover who is also in search of him. After a long journey, Inao meets Butsaba and returns to his kingdom to succeed his father to the throne as the king of Kurepan.

\section{Inao of King Rama II as a Panji Story}

The story of Inao comes from the Javanese and Malay Panji stories. From the comparative study between Inao and 33 Javanese and Malay Panji stories. The 33 Javanese and Malay Panji tales that were used for the comparative analysis in this paper are: 1. Waybay Wideya, 2. Malat, 3. Hikayat Panji Kuda Semirang, 4. Hikayat Andakan Pénurat, 5. Hikayat Panji Semirang, 6. Hikayat Chekel Waneng Pati, 7. Angron Akung, 8. Bentara Keripan, 9. Galuh Digantung, 10. Geguritan Mantri Alit, 11. Geguritan Pakang Raras, 12. Serat Panyi Yayakusuma, 13. Ande Ande Lumut, 14. Panji Kuda-Narawangsa, 15. Jaka Kembang Kuning, 16. Waseng, 17. Phongsawadan Inao Chabap Ari-nakkhara, 18. Jayalengkara, 19. Kelana Wira Jayeng Sakti, 20. Pandji, 21. Pandji (Angreni) Palembang, 22. Panji Jayengtilem, 23. Panji-Malat Cycle, 24. Panji Narawangsa, 25. Panji Wayang Gedhog, 26. Raden Panji, 27. Sekar Taji, 28. Syair Carang Kulina, 29. Syair Ken Tambuhan, 30. Syair Misa Gumitar, 31. The Wedding of Sekar Tadji and Pandji, 32. Tjerita Pandji dalam Serat Kanda, 33. Wawacan Dewi Sekartaji.

The study reveals that Inao preserves three major characteristics of the Panji stories: (1) the plot and theme, (2) the characteristics of the hero and the heroine and (3) Javanese and Malay culture.

\section{1) The Preservation of the Typical Plot and Theme of the Panji Stories in Inao}

The study of 33 Javanese and Malay Panji stories finds that the plot of the Panji stories generally starts with (1) the birth of the hero and heroine who are cousins. In Inao, the hero is called "Inao" and the heroine is called "Butsaba". (2) Their engagement is arranged by their parents. (3) Later, an event causes the hero and the heroine's separation. (4) Thus begins their journey to search for each other. During this journey, the hero and the heroine usually hide their identities by disguising themselves or by being disguised by a god. Amidst his adventures, the hero has a chance to meet the heroine, but they do not recognize each other due to their disguises. (5) However, after the long journey, when they reveal their identities, they 
can recognize each other and reunite happily. (6) Then, they return to their kingdoms and succeed to the throne as the king and queen of the hero's kingdom.

Similarly to the Panji stories, the story of Inao maintains the typical plot, as can be seen in the synopsis.

Also, the story of Inao maintains the main theme of the Panji stories in focusing on the loves and adventures of the hero, as well as his heroic exploits.

\section{2) The Transfer of the Hero and Heroine's Heroic Roles and Ideal Characteristics from the Panji Stories to Inao}

Similarly to the hero of the Panji stories, Inao, the crown prince of Kurepan, is given the "heroic image" through which he possesses all kinds of superior qualities. He is a great warrior who can conquer anyone in battle and is a charming hero to women.

Similarly to the heroine of the Panji stories, Butsaba, the princess of Daha, is presented as an ideal princess who possesses ideal beauty, irresistible charm, good manners and great virtue. Butsaba also expresses her courage and takes on the role of a warrior, like the heroine in some Panji stories such as the Hikayat Panji Semirang.

\section{3) The Presentation of Javanese and Malay Culture Derived from Javanese and Malay Panji Stories in Inao}

Examples of Javanese and Malay culture can be seen in the ritual in which a wife immolates herself after the death of her husband (membela), the thanksgiving ceremony (membayar kaul), the use of the keris (Javanese dagger) and the use of shadow puppets (wayang kulit). Javanese and Malay culture is significant to the story and performance of Lakhon Nai, the Thai court dance drama. For example, the use of the keris led to the development of a solo weapon dance.

The reasons why these typical aspects of the Panji stories are preserved in Inao might be that the romantic plot and theme of the Panji story are universally appealing. Furthermore, the heroic deeds and ideal images of the hero and heroine as a great prince and princess suit the tradition of Lakhon Nai, in which the performance is traditionally fixed to present a heroic and romantic tale depicting the ideal images of a king and queen (or a prince and princess) who have great virtues, in order to support the king who is the owner of the performance.

\section{Inao of King Rama II as a Masterpiece of Thai Court Drama Literature: The Adaptation}

The study finds that the poet uses many techniques to appropriately adapt Inao for a Lakhon Nai performance as well as to qualify for literary beauty. Before addressing the adaptation of Inao from the Panji stories, I would like to provide information about Lakhon Nai, which is the main context of the story's adaptation. Lakhon Nai, or Thai court dance drama, has its own tradition that is quite distinct from other Thai dance dramas. Below is the brief information about Lakhon Nai summerized from the explanation of Prince Damrongrachanuphap (1965: 10-56). 
a) Lakhon Nai functions as royal entertainment, especially for the king, and also as a performance in various state and royal ceremonies.

b) Lakhon Nai consists of music, dance and drama. Generally, it is performed by female dancers. There are no clowns or comic scenes in Lakhon Nai.

c) Lakhon Nai proposes to demonstrate and represent the perfect beauty and the high degree of skill demonstrated in court arts, such as the art of dancing, singing and literature. Thus, dancing in Lakhon Nai is performed slowly and smartly in order to emphasize the high quality of various kinds of arts, such as the art of singing, dancing and the literary beauty of the text. The performance of one episode might take a few hours or a few days.

d) The dance style and movement in Lakhon Nai is slow, smart, graceful and delicate, in order to clearly reveal the dancers' artistic skills. The scripts for Lakhon Nai generally contain long and various descriptions that are appropriate to chanting and dancing slowly.

The tradition of Lakhon Nai is the main reason for the adaptation of Inao. This study finds that there are four main techniques the poet uses to compose and animate the story - (1) creating many romantic and attractive scenes, (2) adding certain aspects of Thai culture that are significant to the story, (3) characterizing the main characters as lively individuals and (4) using artful language and descriptions.

\section{1) The Creation of Romantic and Appealing Scenes}

There is no evidence indicating which version of the Panji story influences most the story of Inao, but the comparative study between Inao and 33 Javanese and Malay Panji stories can be helpful in drawing ideas on the adaptation of Inao.

The comparative study finds that Inao contains many romantic and appealing scenes that are unique compared to other Panji stories in which they do not take place. These scenes might be considered as Thai creations, for example:

- the scene in which Inao flashes his keris (dagger) to attract Butsaba to see him,

- the scene in which a hermit sprinkles holy water on Inao and Butsaba and blesses them both with long lasting love,

- the scene in which Butsaba consults a sacred sculpture about her soulmate through the candle light ${ }^{1}$ ("Butsaba and the Candle Prophecy"),

- the scene in which Inao disguises himself as a soldier and rides a horse to see Butsaba who is in the chariot on the way back from the mountain to the palace of Daha.

The creation of such scenes places greater emphasis on romantic elements, fascinates the readers and the audience, and becomes suitable to be transformed into highly skilled dances.

I would like to choose two scenes as main examples: the scene in which Inao flashes his keris (dagger) to attract Butsaba (Inao Chai Krit) and the scene of "Butsaba and the Candle Prophecy" (Butsaba sieng thien). These two scenes happen in the episode

\footnotetext{
${ }^{1}$ This scene was performed at the SEAMEO SPAFA Panji/Inao Traditions in Southeast Asia event on 2 March 2013 by the Troupe of the Office of Music and Drama, Fine Arts Department, Ministry of Culture. It can be viewed at https://www.youtube.com/watch?v=PK6eqZ_AA8c.
} 
in which the king of Daha, Butsaba's father, makes the thanksgiving ritual or the vow fulfillment ceremony at Wilitsamara Mountain after winning the war.

The scene in which Inao flashes his keris to reflect sunlight into Butsaba's eyes to attract her attention (Inao Chai Krit)

During the trip to the mountain, Butsaba and her maids take a walk around the forest and pick some flowers. When Inao sees Butsaba sitting to choose some flowers, he walks near her and flashes his dagger in order to catch her gaze. However, upon seeing the shine of his dagger, she is frightened and faints suddenly.

This scene is very famous and is often performed. Interestingly, the use of the keris in the scene is quite different from Javanese and Malay tradition. Generally, in Javanese and Malay culture, the keris would be drawn out for the purpose of fighting only, and it is believed that when the keris is drawn out, it would draw blood (Chalemphao Koanantakul 2001: 70). The use of the keris in this scene is a romanticization as it is used in a romantic way. It might be a Thai poetic creation in order to show how Inao is clever in creating a romantic trick to attract the heroine, as well as to add a scene that would allow the dancer who represents Inao to show off her high level of skill in "weapon dancing" (Ram Inao Chai Krit).

\section{The scene of "Butsaba and the Candle Prophecy" (Butsaba Sieng Thien)}

In this scene, Madewi, the second queen of Daha, asks Butsaba to consult a candle in front of a sacred sculpture in a cave because she worries over who Butsaba's soulmate is. In the text, the poet does not inform what the sculpture is. The poet just uses the word patima, which means an image or a sculpture, to describe the sacred sculpture, so it depends on the reader's or the audience's imagination or interpretation.

Madewi asks Butsaba to light three candles representing herself, Inao and Choraka, her new fiancé. She asks the god to extinguish the candle representing the one who is not her soulmate. During this time, Inao secretly follows her into the cave and hides behind the image of the sacred sculpture. When Butsaba asks the god her question, Inao gives her the answer. He intends to deceive her by pretending that his voice is the voice of the god. Through this voice, Inao convinces Butsaba and Madewi that Butsaba's soulmate is Inao. Moreover, he asks Prasanta, his follower, to drive out the bats in order to put out the candles. Then, in the darkness, he comes out to touch, kiss and hold Butsaba in a loving embrace. When Madewi finds that Inao is in the cave holding Butsaba, she becomes very angry. Inao then claims to her that Butsaba belongs to him because he is her real fiancé. Madewi argues that he is not Butsaba's fiancé because he himself has refused to marry her. Inao defends himself by saying that he has never refused her. Madewi asks Inao to release Butsaba from his hold. Inao then asks Butsaba for a piece of cloth to hold in his possession when he misses her.

The "candle prophecy", as depicted in the scene, is an ancient Thai ritual. It was recorded in a historical manuscript from the Ayutthaya period that Khun Phirentharatep asked an image of the Buddha who would be the King between Khun Worawongsathirat and Phra Tienraja through the two candles representing the two persons (Phrachumphongsawadan Chabab Kanchanaphisek Vol.1 1999: 227-228) 
This is a very romantic and famous scene in Inao that is often performed. The poet creates this romantic scene in order to incorporate a chance for Inao to touch and hold Butsaba, as well as to allow him to express his love to her directly. As a result, Inao is madly in love with Butsaba and develops his passionate love towards her, as he sees her beauty closely and has a chance to touch her.

\section{2) The Addition of Certain Aspects of Thai Culture that Are Significant to the Story}

One of the unique elements of Inao as a Thai literary work is that the story presents various kinds of Thai court rituals and ceremonies, most of which are court rituals and ceremonies that were held in the court from the Ayutthaya to early Bangkok period, for example:

- the candle prophecy,

- the royal Thai cremation ceremony,

- the royal topknot cutting ceremony,

- the royal Thai coronation ceremony,

- the holy water pouring ceremony after winning a war,

- the royal Thai wedding ceremony.

The Thai court rituals and ceremonies presented in Inao are all described explicitly. These rituals and ceremonies do not only localize the story so that they may be more familiar to the Thai audience, but are also significant to the life and role of the main characters of the story. For example:

- the royal Thai cremation ceremony is added in the episode in which Inao's grandmother dies;

- the holy water pouring ceremony in which a king receives holy water poured by a Hindu priest after winning a war is added in the scene in which Inao, the hero, wins the war against the king of Kamangkuning who wants Butsaba to marry his son;

- the royal topknot cutting ceremony is added to the story when Siyatra, the heroine's younger brother, turns fifteen years old, the age at which one undergoes the topknot cutting ceremony;

- the royal Thai wedding ceremony is described in the scene in which Inao marries Butsaba.

The royal Thai cremation ceremony (Ngan Phra Men) in the story will be examined here. The royal cremation ceremony is inserted into Inao in the episode in which Inao's grandmother passes away in the kingdom of Manya. By the king of Kurepan's command, Inao goes to attend the ceremony. This leads him to meet Chintara, the princess of Manya, for the first time. He falls in love with her at first sight, which makes him decide to break off the engagement with Butsaba, the princess of Daha, who he has never met. His decision makes his father, the king of Kurepan, and his uncle, the king of Daha, very upset and angry. Chintara, in the Thai version, has a role and status similar to that of "Angreni" in other Panji stories, since she is the hero's first love that his family do not accept, but Chintara is not killed like Angreni is in some Panji stories.

In this episode, the poet describes the royal cremation ceremony of Inao's grandmother very explicitly by giving details of all the steps and procedures of the ceremony, which are strictly defined in the Ayutthaya and early Bangkok court 
traditions. The poet details many elaborate preparations of the ceremony such as the construction of the crematorium and the decorating of the royal carriages used in the procession to transport the royal urn from the palace to the ceremonial ground of the city. The poet also describes all the rites and rituals involved in the ceremony stepbystep. It is described that when the crematorium built in the ceremonial ground of the city is completed, the deceased is transferred from the palace to the crematorium accompanied by the procession of honour. This rite is called "Ok Phra Men" in Thai. The ceremony is celebrated for seven days. After the royal cremation, the relics of Inao's grandmother are transferred in a procession of honour to the palace, while her cremated ashes are scattered over a river. All of these procedures of the Thai royal cremation are described in Inao of King Rama II.

This cremation ceremony is inserted into the episode significantly. The poet uses the ceremony as a romantic scene for Inao to express his love to Chintara, as all rites and rituals involved in the ceremony provide Inao with a chance to see Chintara again and again. For example, in the scene in which Inao and Chintara pay their respect to the deceased in the palace, Inao reveals many signs of his love for Chintara through body language, such as making steady eye contact with her, getting close to her and taking his shoulder to touch her shoulder and holding her hand softly. As a result, Inao develops his passionate love towards Chintara through this scene. It should be remarked that the Thai court rituals and ceremonies inserted in Inao also relate to the cultural context of the early Bangkok period in which the text was composed. The early Bangkok period is a time of "restoration". When Bangkok was established by King Rama I, the king restored most of the social, economic and political systems, as well as reinstated the arts and court ceremonies of the Ayutthaya period. The time of "restoration" was continued during the reign of King Rama II. The reason why King Rama II presented and described many Thai court rituals and ceremonies explicitly in Inao might be that the king intended to record the knowledge of Thai court culture that had already been restored at that time, as well as to proudly announce and affirm to his people that the knowledge and the tradition of the Ayutthaya period had been retained.

\section{3) Characterizing the Main Characters}

As Lakhon Nai, some characters in the story are characterized as emotional, lively and attractive to the Thai audience. The two characters of Inao and Choraka will be exemplified here.

Inao, the hero

Inao in the Thai version is characterized as a charming, gentle and emotional hero. In the story, Inao expresses various feelings that make him human and lively. For example:

- When Inao sees Choraka, the ugly king who asks for Butsaba's hand after Inao breaks off the engagement, the poet describes that Inao is so angry and jealous of Choraka, his competitor, that he wants to kill him, but he manages to calm himself down.

- For Siyatra, Butsaba's brother, Inao clearly expresses his love and kindness towards him. For example, when Siyatra tells him that his sister hits him, Inao comforts the child by giving him flowers and holding him to ride a horse. 
- For Butsaba, Inao expresses not only his guilt and regret for previously refusing her, but also his love and strong desire for her. For example, when Inao falls in love with Butsaba at first sight, his love and his impression of her beauty arouses him to improvise and sing a love poem suddenly, without being aware that he is in the royal hall. The poet describes his reactions to the beauty of Butsaba as follows: his body sweats heavily, his hands fall and he kisses Siyatra, Butsaba's brother, unconsciously many times, mistaking Siyatra for Butsaba.

The poet also humanizes Inao as a hero who plays tricks on people. The story depicts Inao deceiving people in order to get a chance to meet and express his love for Butsaba. There are many scenes revealing his trickery, for example:

- In the scene in which Butsaba makes the candle prophecy, Inao follows her secretly into the cave and hides behind the sacred image, in order to wait for a chance to hold and kiss her.

- In the scene in which Butsaba is bathing in the stream on the mountain, Inao devises a plan to make Butsaba and Madewi angry with Choraka. Inao floats a love letter towards Butsaba, in order to create the misunderstanding that the letter is from Choraka, so that Butsaba would be angry with Choraka. Inao writes in the letter that he looks forward to being married with her very soon. Butsaba and Madewi fall for Inao's trick and, believing that Choraka wrote the letter, become angry with him.

It can be seen that Inao, as a character, combines two images: the ideal and the realistic. He does not only portray the image of the ideal prince, but also represents the image of an emotional human being capable of deceiving others, which clearly adds colour to the story, making it lively and appealing to the Thai audience.

\section{Choraka, the ugly king}

Choraka is a king who is the first man who asks for Butsaba's hand after Inao breaks off the engagement with her. The king of Daha, Butsaba's father, is so angry with Inao that he gives Butsaba to Choraka. In many other Panji stories, there is a character that takes on a similar role to that of Choraka, but with different names. However, Choraka's appearance and characteristics are different to those of characters with a similar role from other Panji stories.

The Thai poet characterizes Choraka as having all kinds of imperfections. Choraka is presented as an ugly king who is fat and has an ugly face, curly hair, dark skin and a hoarse voice. His dynasty is lower and incomparable to those of Inao and Butsaba. He always falls victim to Inao's trickery.

For example, in the scene in which the king of Daha makes the votive offering on the mountain, Inao and Choraka have to chant one by one as an offering to the god in the ritual. Through the song, Inao criticizes how a man may dare to ask for the divine flower that belongs to him and expresses how he would like to defeat that man. The man in the song is a reference to Choraka who has asked for Butsaba's hand. This song makes Choraka feel very angry, so, when it is his turn, he improvises a song to criticize Inao, but Inao hits the drum loudly in order to drown out Choraka's voice. 
Therefore no one hears Choraka's satirical song. This obviously reflects Inao's cleverness and trickery, and how Choraka falls victim to him.

Choraka's appearance and characteristics as put forward by the Thai poet intends to characterize Choraka as the complete opposite of the hero. Inao and Choraka are thus like a "binary opposition". Inao represents perfection, while Choraka represents the opposite. Choraka's imperfect character clearly underlines the greatness and ideal characteristics of Inao. It is a literary technique that can be found in many works of Thai literature.

\section{4) The Use of Artful Language and Descriptions}

Finally, Inao is outstanding for its exquisite language and descriptions in expressing strong emotions and arousing the imagination, which are the major characteristics of Thai court drama literary tradition.

The poet develops the story by elaborating various kinds of descriptions, for instance:

- the descriptions of the beauty of the characters (Bot Chom Chom),

- the descriptions of the clothing and adornments of the characters (Bot Sa Song Song Khreung), such as those of Butsaba and Inao,

- the descriptions of the royal chariot (Bot Chom Rot),

- the descriptions of the royal horse (Bot Chom Ma),

- the descriptions of the royal army (Bot Chom Thap),

- the descriptions of beautiful scenery (Bot Chom Sathanthi), such as the forest, the stream and the palace,

- the descriptions of the characters' emotional expressions and lamentations (Bot Ramphan), such as the emotions of Inao and Busaba.

These various descriptions not only enhance the literary beauty of the text and evoke the imagination of the audience, but are also significant to the performance, since in the tradition of Lakhon Nai, these descriptions enable the dancers to reveal their highly developed skills in dancing. For example, Bot Sa Song Song Khreung (the descriptions of the clothing and adornments of the characters) can be performed as a solo dance in order to highlight the dancer's talent and skill.

In addition to the beautiful descriptions, Inao of King Rama II is outstanding for its exquisite language, which still touches the hearts of Thai people. The following is an example:

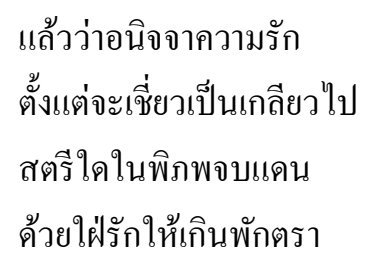

$$
\begin{aligned}
& \text { พึ่งประจักษ์ดั่งสายน้ำไหล } \\
& \text { ที่ไหนเลยจะไหลคืนมา } \\
& \text { ไม่มีใครได้แค้นเหมือนอกข้า } \\
& \text { จะมีแต่เวทนาเป็นเนืองนิตย์ }
\end{aligned}
$$

Translation: Chintara realizes that love is like the current of a river from which there is no return. No woman in the world has suffered as much as she. Since she does not realize that she is merely a princess 
from a humble rank, she suffers from love [with Inao, a high ranking prince]. (Phutthaloetlanaphalai 1971: 305)

The quotation cited above is about Chintara, Inao's first love, from the farewell scene in which Inao tells Chintara that he has to leave her to help the king of Daha, his uncle, fight against the king of Kamangkuning. This causes Chintara to be very upset and bitterly disappointed since this war will certainly lead Inao to meet Butsaba, his fiancée, who is very beautiful. Chintara knows that Inao will undoubtedly fall in love with Butsaba and will never come back to her. To this day, this quotation is still well known among Thai people.

\section{Conclusion}

The aim of this paper is to examine how Inao of King Rama II was transformed from the Panji stories into a new genre, within the context of a Thai court dance drama. This study reveals that Inao of King Rama II developed from the Panji stories and contains various elaborations, embellishments and innovations, in order to serve the purposes and function of Lakhon Nai and Thai literature.

As a result of a perfect combination of elements and prominent features from other Panji stories and new creations in its Thai adaptation, Inao has become a reference for excellence in literature and the performing arts. Inao of King Rama II does not only portray the heroic and idealistic role of the hero, but also humanizes him as an emotional and deceiving individual that is skilled at pleasing women. The story also places greater emphasis on the romantic scenes and on the strong expression of affection between the hero and the heroine, instead of highlighting the battle scenes. This study finds that the poet intentionally extends and highlights the episode in which Inao meets and falls in love with Butsaba in the kingdom of Daha by collecting and creating many romantic scenes, as well as elaborating the descriptions of the hero's emotional expressions and lamentations in the episode. Not only are these descriptions of emotional expression harmonious with Thai literary tradition, but also they correspond to the attributes of the tradition of Lakhon Nai in which the dances performed represent long descriptions and focus on the expression of emotion.

The romantic scenes between Inao and Butsaba are the most popular among the Thai audience and clearly reflect Thai creativity, which is what makes Inao of King Rama II unique in comparison to other Panji stories. In addition, Inao of King Rama II is outstanding for its combination of Thai, Javanese and Malay cultural elements, all of which are important to the story and performance. For example, the ritual in which a wife immolates herself after the death of her husband (membela) can be transformed into a highly skilled keris dance in Lakhon Nai, or the ritual of the candle prophecy provides a chance for the hero to meet and express his desire for the heroine. The mixture of "Thainess" and "otherness" in Inao increases the charm of the story and makes the story unique compared to other Panji stories as well as other Thai court dramas.

Inao of King Rama II, therefore, evidences the ability and wisdom of the poet in transforming Southeast Asian tales into a masterpiece of Thai court drama literature that has become a favourite among the Thai audience as a work of literature and 
performance. Although Inao of King Rama II was composed over two hundred years ago as a specific genre and within a specific context, this text has remained highly valued in Thai society to this day. Not only does Inao entertain Thai people, but it also passes down knowledge and provides inspiration to Thai artists. At the beginning, around the early Bangkok period, Inao was only influential within the confines of the royal palace, but later Inao became extensively popular and significant to the masses. Inao of King Rama II, therefore, is an important piece of Thai cultural heritage.

\section{Acknowledgements}

This paper is a part of the author's PhD dissertation entitled "Inao of King Rama II: The Making of the Panji Cycle into a Masterpiece of Thai Court Drama Literature". Professor Dr Cholada Ruengruglikit, the author's advisor, and the author acknowledges the financial support in part by a Chulalongkorn Graduate Scholarship Commemorating the $72^{\text {nd }}$ Birth Anniversary of HM King Rama IX and by the Thailand Research Fund through the Royal Golden Jubilee PhD Programme.

\section{Bibliography}

Chalemphao Koanantakul, P (2001) Krit phuuying la khwamtai nai lakhon ram, [Kris, women and death in dance theatre, in Thai] Muengboran 27(1): 68-80. Google Scholar search

Damrongrachanuphap, Somdetphrachaoborommawongthoe Kromphraya (1965) Tamnan Lakhon Inao [Legend of Inao Drama, in Thai]. Thonburi:

Po. Phitsanakha Publishing. Google Scholar search

Office of Literature and History, Fine Arts Department (1999)

Phrachumphongsawadan Chabab Kanchanaphisek [Chronicle: Golden Jubilee Edition, in Thai] Vol.1. Bangkok: Office of Literature and History, Fine Arts Department. Google Scholar search

Phutthaloetlanaphalai, Phrabatsomdetphra (1971) Rueang Inao [Inao Story, in Thai], $11^{\text {th }}$ edn. Bangkok: Bannakhan. Google Scholar search

Robson, S O (ed. and trans.) (1969) Hikajat Andaken Penurat [The Legend of Andaken Penurat, in Bahasa Indonesia]. The Hague: Martinus Nijhoff. Google Scholar search 